\title{
Europe's Conservation Year, 1970
}

Shortly after my arrival in France last January, the Council of Europe held a Conference in Strasbourg on the protection of the environment. Thus was launched Europe's Conservation Year, in which over 20 countries, from Iceland to Turkey, are participating. The Council is a consultative rather than a legislative body, but it unanimously supported the declaration that the protection of Europe's natural environment must have high priority in each government's national policy and budget. In addition, and as rapidly as possible, international standards must be established in the fight against the pollution of air, water and soil. The Conference charged the Council to add to the European Convention of the Rights of Man the right of everyone to a healthy and intact environment, to breathe air and drink water that are reasonably safe, not to submit to excessive noise, and to have reasonable access to the sea and countryside. "At Strasbourg", concluded the Conference president, "a window has been opened on a better future for man."

Concern over the accelerating destruction and pollution of man's environment could well be the most characteristic feature of the evolution of public opinion in the last decades of this century. An example of a thoughtful Conservation Year programme was described to me when I was in Northern Ireland at Easter where, paradoxically, headlines were being made by destructive rioting in Belfast. It was an extension course sponsored by the $N$ ew University of Ulster and the Queen's University of Belfast on conservation in relation to the local environment. One lecture, for example, explored the ecological compatibility of the various uses made of Lough Neagh, the largest lake in Great Britain.

More than most nations, perhaps, the British have been aware of their natural environment as a precious heritage. British poets have traditionally celebrated the beauties of the countryside, and in April of this year Wordsworth's favourite walks in the Lake country were recalled in the bi-centennial celebration of his birth. Travellers to Britain are enchanted to find how much country landscape is still intact, and how many country customs are still alive. It is possible to have a ploughman's lunch in a village pub, and to join a group of bell ringers in the tower of a village church (as I did at Hayfield in Derbyshire) to watch them ring for a wedding or a morning service. Europeans understand that these patterns of life, like the old Norman church threatened by a new motorway, have their role to play in a meaningful environment. In the heart of the great city of Paris today, a fine job is being done in cleaning up and restoring the historic quarter of the Marais.

From this broad cultural meaning of the word "Conservation," we come back to its more limited sense as the wise use of man's natural environment. On the Canadian prairies we take natural surroundings and open space for granted. But these are luxuries in crowded parts of Europe. So it is reassuring to find that there are long sweeps of Normandy coast where one can walk alone on the sands, at least in winter. Or that up on the lonely Yorkshire moors in an early April snowstorm one can still feel shut off from the rest of the world. Or that one can spend an afternoon undisturbed watching migrant ducks and waders on the windswept tidal marshes of the Lune and Wyre River estuaries. All of these experiences I have had in Europe in this Conservation Year, and they make it seem overwhelmingly important that man's struggle to protect his environment should not fail.

Margaret Belcher,

Paris, April 1970. 